\title{
Recombinant activated factor VII as treatment for uncontrolled mucosal haemorrhage
}

\author{
J Gracia, ${ }^{1}$ Prieto ${ }^{2}$ \\ ${ }^{1}$ Department of ICU, Ramon y Cajal Hospital, Madrid, Spain; \\ 2Department of Medical ICU, Ramon y Cajal Hospital, Madrid, Spain \\ Correspondence to J Gracia, jan.grazia@gmail.com
}

\section{Summary}

We report the use of a haemostatic drug (recombinant activated factor VII (rFVIla)) in a patient who presented a slow but constant bleed in oesophageal mucosa (which required frequent red blood cell transfusion) due to ingestion of caustic products. The administration of $\mathrm{rFVIla}$ ceased bleeding and allowed mucosal cicatrisation and patient haemodynamic stabilisation and clinical recovery.

\section{BACKGROUND}

This case shows how recombinant activated factor VII (rFVIIa), a haemostatic drug, may help us to prevent a fatal haemorrhage. Preventive administration of rFVIIa has not been widely used in the past.

\section{CASE PRESENTATION}

A 31-year-old man attempted suicide by ingesting approximately $200 \mathrm{ml}$ of a caustic product (composition: buthyldiglycol, fatty ethoxylated alcohol, monoethanolamine, diethanolamine, triethanolamine, sodium tripolyphosphate; used for domestic cleaning) and presented to the emergency room unconscious (Glasgow Coma Scale 7) but haemodynamically stable (blood pressure 120/80 mm Hg, heart rate 90 beats per minute). Chest x-rays were normal and there were no relevant findings in blood analyses.

Erythematous lesions without signs of bleeding were observed in the mouth and oropharynx with a flexible fibrescope. After orotracheal intubation, a CT with intravenous contrast revealed oesophagus collapse with marked parietal thickening of the gastric submucosal oedema, thickening of the gastric folds and of the duodenum and jejunum wall.

Steroids (methyl-prednisolone $1 \mathrm{mg} / \mathrm{kg}$ daily) and prophylactic antibiotic treatment with piperacillin-tazobactan was started together with somatostatin, pantomycin and pantoprazole. Parenteral nutrition was started. Further CT studies performed on days 3 and 8 of admission to the intensive care unit (ICU) showed bilateral pleural effusion with compressive atelectasis of the posterior segments; thickening of the oesophageal and gastric walls and erasing of the adjacent fat. There was severe duodenal dilation with internal haematoma (figure 1). A week after admission an oral panendoscope (PEO) revealed oesophageal-gastric diffuse mucosal bleed and subjacent necrosis. A gastrointestinal transit with contrast demonstrated oesophageal stenosis, insufficiency of Oddi's sphincter and anatomic alterations at the bulbar level with severe obstruction on contrast passage (figure 2). Fibrobronchoscopy revealed an airway without lesions.
The patient presented a constant blood loss through the naso-gastric probe (NGP), haematic buccal secretions and daily melena. Coagulation assays and platelet counts were in the normal range. Haemoglobin level was persistently low ( $<80 \mathrm{~g} / \mathrm{l})$ during ICU stay requiring transfusion of up to 18 red blood cell (RBC). Replacement treatment with blood derivatives did not stop the bleeding. A PEO revealed profuse haemorrhage of unknown origin. Cauterisation of the otorhinologic region with argon laser produced only partial remission of the bleeding.

\section{TREATMENT}

The rFVIIa was administered at a dose of $100 \mu \mathrm{g} / \mathrm{kg}$ every $6 \mathrm{~h}$ due to the haemostatic inefficacy of replacement treatment and failure to localise the site of the haemorrhage (and the assumption of a diffused haemorrhage throughout the extensive damaged area of the digestive tract). A total of five doses were administered using a haemoglobin figure as a control parameter of drug response.

\section{OUTCOME AND FOLLOW-UP}

After drug administration, and in the following hours and days, the haemoglobin figures stabilised and haematic loss in the NGP and of the mucosal bleeding in the oral cavity ceased. The patient was discharged with no further signs of either bleeding or anaemia.

\section{DISCUSSION}

Caustic ingestion is a cause of intense morbidity for two reasons: first, ingestion of these products provokes inflammation, destruction and, at times, perforation of the digestive tract producing the potentially fatal complications of mediastinitis and peritonitis-haemorrhage can present as a complication; second, the inflammatory lesions can generate potentially severe cicatricial lesions. ${ }^{1}$ Management of these lesions is at first usually conservative by restricting the use of endoscopes for diagnostic and prognostic purposes. At a later stage surgical correction, if possible, of the cicatricial complications that present is undertaken. ${ }^{2}$ The usual haemostatic treatment when significant haemorrhage and 


\section{BMJ Case Reports}

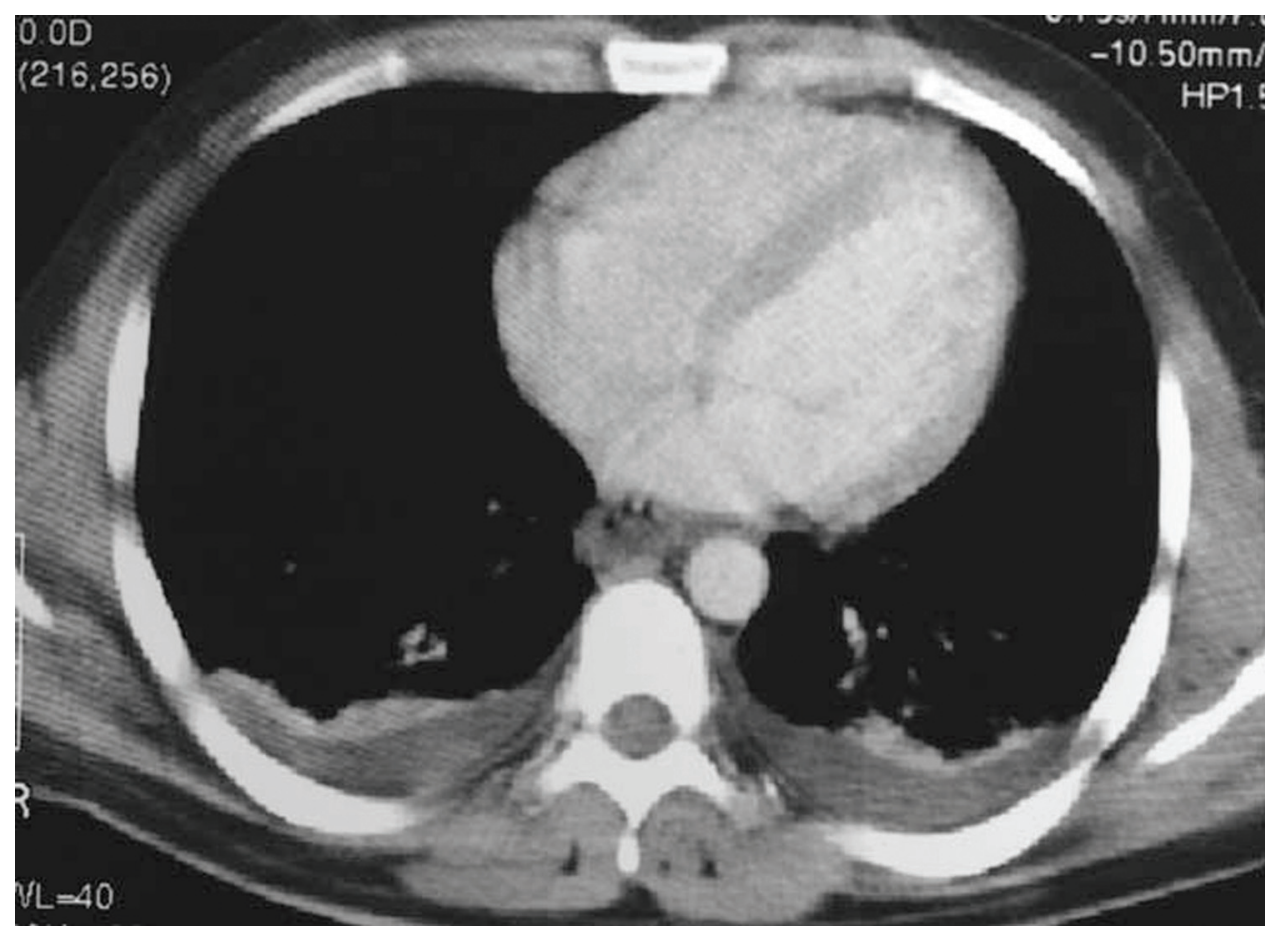

Figure 1 Abdominal CT scan showing thickening of the oesophageal wall.

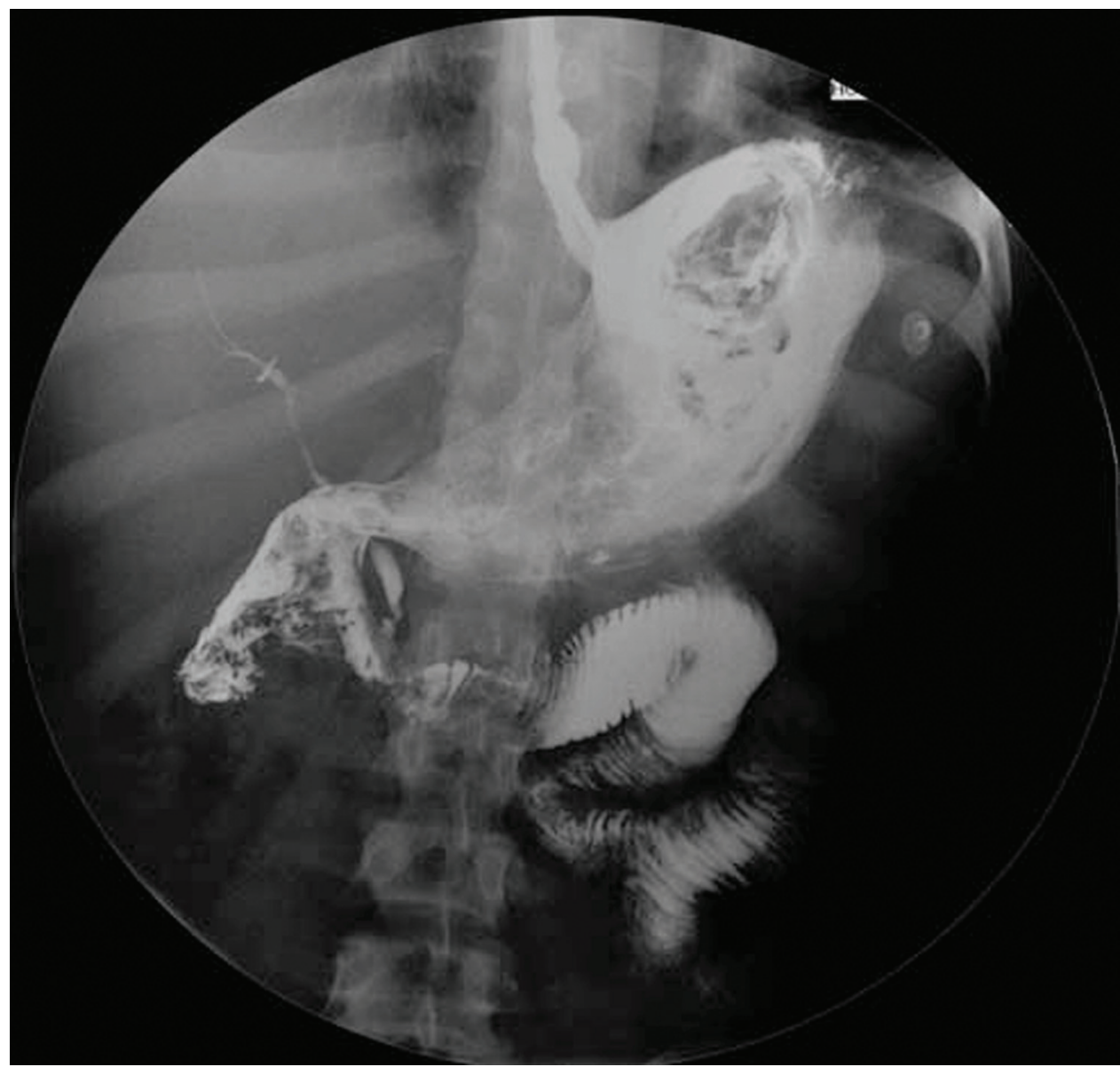

Figure 2 Gastrointestinal transit showing anatomic gastrointestinal tract alterations. 
anaemia are present is replacement treatment. Despite it, bleeding can at times persist particularly in those patients with acquired coagulation defects. rFVIIa (Novoseven; Novo Nordisk, Bagsvaerd, Denmark) was originally developed for the treatment of bleeds in congenital haemophilia with inhibitors. Other approved indications are congenital FVII deficiency, acquired haemophilia and Glanzmann thromboasthenia. ${ }^{3}$ However, an increasing number of publications report uses outside the current approved indications with high haemostatic efficiency and a low rate of adverse effects. ${ }^{4} 5$

We report the case of a patient with diffused digestive bleeding produced by a mucosal lesion in an uncompleted phase of cicatrisation, which caused mild but constant haemoglobin decrease requiring periodic transfusion.

\section{Why rFVIla?}

Mucosal digestive bleeding from the mouth to the jejunum appears to be the probable cause of the continuous anaemia of the patient. The exact source of bleeding was not observed by the endoscopic studies; instead they establish the diffuse origin of the bleeding and, thus, rule out endoscopic treatment. Selective arterial embolisation was not appropriate in this context not only for the diffuse origin of the bleeding but also for its low rate (the bleeding point was not detected in $\mathrm{PEO}$ or CT). This technique should be reserved for bleeding in which the responsible vessel is clearly identified. The replacement of coagulation factors and RBC is not always capable of stopping the bleeding particularly in situations as this in which the deficiency of these components is not the reason for transfusion. Thus, rFVIIa was used for its proven capacity of inducing haemostasis in different situations with acquired coagulopathies.

\section{Why a dose of $100 \mu \mathrm{g} / \mathrm{kg}$ ?}

rFVIIa has a double mechanism of action. First, physiological doses of rFVIIa are able to replace the possible FVII deficit (eg, congenital): this effect is obtained with low doses of the drug $(15-30 \mu / \mathrm{kg})$. Second, supraphysiological concentrations of $\mathrm{rFVIIa}$ (a dose of $\geq 90 \mu / \mathrm{kg}$ ) generate thrombin in the surface of the locally activated platelets in the absence of a coagulation factor or in situations that limit the coagulation process (ie, hypothermia, acidosis). ${ }^{6-9}$

\section{Learning points}

- Any type of acquired coagulopathy haemorrhage is not within the approved indications of the drug.

- We consider that the drug should be listed within the possible therapeutics for patients, such as our case, with slow but constant bleeding that prevents the process of digestive mucosa recovery and who require frequent periodic transfusions.

Acknowledgements We thank the hospital ICU staff and surgery team for the care of this patient during his stay in the hospital.

Competing interests JG was, in the past, medical adviser for Novo Nordisk.

Patient consent Obtained.

\section{REFERENCES}

1. Ramasamy $\mathbf{K}$, Gumaste W. Corrosive ingestion in adults. J Clin Gastroenterol 2003;37:119-24.

2. Nunes AC, Romãozinho JM, Pontes JM, et al. Risk factors for stricture development after caustic ingestion. Hepatogastroenterol 2002;49:1563-6.

3. Hedner U. Recombinant factor VIla (Novoseven) as a haemostatic agent. Semin Hematol 2001; 38:43-7.

4. Welsby IJ, Monroe DM, Lawson JH, et al. Recombinant activated factor VII and the anaesthetist. Anaesthesia 2005;60:1203-12.

5. Roberts HR, Monroe DM 3rd, Hoffman M. Safety profile of recombinant factor Vlla. Semin Hematol 2004;41:101-8.

6. Hedner U. Mechanism of action of factor VIla in the treatment of coagulopathies. Semin Thromb Hemost, 2006, 32:77-85.

7. Hedner U. Recombinant factorVlla: its background, development and clinical use. Curr Opinion Hematol 2007; 14:225-9.

8. Vincent JL, Rossaint R, Riou B, et al. Recommendations on the use of recombinant activated factor VII as an adjunctive treatment for massive bleeding - a European perspective. Crit Care 2006;10:R120.

9. Erhardtsen E. Pharmacokinetics of recombinant activated factor VII (rFVIlla) Semin Thromb Hemost, 2000;26:385-91.

This pdf has been created automatically from the final edited text and images.

Copyright 2011 BMJ Publishing Group. All rights reserved. For permission to reuse any of this content visit http://group.bmi.com/group/rights-licensing/permissions.

BMJ Case Report Fellows may re-use this article for personal use and teaching without any further permission.

Please cite this article as follows (you will need to access the article online to obtain the date of publication).

Gracia J, Prieto I. Recombinant activated factor VII as treatment for uncontrolled mucosal haemorrhage. BMJ Case Reports 2011;10.1136/bcr.09.2009.2306, date of publication

Become a Fellow of BMJ Case Reports today and you can:

- Submit as many cases as you like

- Enjoy fast sympathetic peer review and rapid publication of accepted articles

- Access all the published articles

- Re-use any of the published material for personal use and teaching without further permission

For information on Institutional Fellowships contact consortiasales@bmjgroup.com

Visit casereports.bmj.com for more articles like this and to become a Fellow 